\title{
Will energy fuel the future of the Turco-Russian relationship?
}

\section{Göktuğ Kara}

To cite this article: Göktuğ Kara (2009) Will energy fuel the future of the Turco-Russian relationship?, Journal of Balkan and Near Eastern Studies, 11:2, 121-139, DOI:

10.1080/19448950902920764

To link to this article: http://dx.doi.org/10.1080/19448950902920764

册Published online: 04 Jun 2009.

Submit your article to this journal $\pi$

WII Article views: 111

Q View related articles $\asymp$

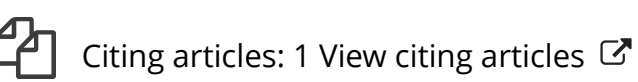


Journal of Balkan and Near Eastern Studies, Volume 11, Number 2, June 2009

Routledge
Taylor \& Francis Group
敢

\title{
THEMES
}

\section{Will energy fuel the future of the Turco-Russian relationship?}

\author{
GÖKTUĞ KARA
}

\section{Introduction}

There is currently a perhaps surprising closeness in the relationship of Turkey and Russia. Historically, of course, the two almost defined themselves in terms of each other. Much Russian history was written in the same fashion as Spanish history used to be, of a centuries long struggle against Islam. Even in Soviet times, the 'Tatar Yoke'-Mongol oppression from the mid-13th to the late 15th century-was a standard theme. Turkish historiography concerning Russia is surprisingly weak, given that Russia, Tsarist or Soviet, was the great enemy. This historic opposition does of course require qualification, and peoples with the geopolitical closeness of Turks and Russians could hardly have been living on the same borders for half a millennium without absorbing much from each other.

The famous Russian expression, 'the Tatar yoke', turns out to have been an invention of the later 16th century, when the Orthodox Church used it as a power play against Ivan the Terrible, who expanded his absolutist power in alliance with Tatars. On the other hand, the Ottoman history does probably not recall its endless struggle with the northern neighbour in glory. The two nations were contenders on a wide geopolitical setting, namely, Caucasus, Balkans and the Black Sea. Although Ottomans had difficult times at the expense of expanding Russian power, there were also historical moments, like 1838, when the Sublime Porte sought the assistance of the Russian Empire to subdue its uprising (Egyptian) subjects.

The rise of the Russian Empire coincided with the decay of Ottoman power. Starting from the late 18th century, the powers occasionally were at war until the end of the First World War, which was instrumental in helping Serbia, Greece and Bulgaria to establish their independent states. The Turkish state usually resorted to diplomacy and the alignments in the international system to block Russian aspirations (such as 1856/Crimean War-European coalition, 1878/St StefanosBerlin International Conference). The Russian Empire usually pursued the role of protector of Orthodox subjects of the Ottoman Empire and generally approached Turkey as the major stumbling block en route to the Mediterranean.

In the first quarter of the 20th century, both states had undergone dramatic change. Declarations of Constitutional monarchies in Russia (1905) and in the Ottoman Empire (1908) were followed by tremendous losses of both countries 
during the First World War. This resulted in the Bolshevik Revolution in Russia (1917) and the Turkish War of Independence (1919-23) and the declaration of the Republican regime in Turkey in 1923. ${ }^{1}$ The nationalist revolutionaries of Ankara were among the first to recognize the communist revolutionaries of the Union of Soviet Socialist Republics. The Turkish resistance movement led by Atatürk sought help from Lenin's Soviets to continue the war of survival against the occupation forces of Greece and Britain. Lenin extended limited support to the Turkish struggle against the 'imperialist' forces ${ }^{2}$ (5 per cent of the Turkish defence budget came from the USSR).

Much later (and this is of some importance in what follows) Turkish nationalists, after the First World War, cooperated with the Russian revolutionaries and even, in a sense, owed victory to that alliance. There was at one stage a square in Izmir named after Voroshilov, who had come on a state visit (the photographic record of which is in the Atatürk Museum at Ankara today). Historically, Turkey had been the weaker element. However, in the 1980s her economy progressed to the point at which a gravitational effect on its nearest and most important neighbour was bound to show. ${ }^{3}$

Where does the future lie? There are various possible perspectives. There is a military one. Turkey has been a member of NATO for more than 50 years. There has been huge investment in this, and, as Turkey has grown substantially in military strength and capability (it now manufactures F-16s and owns the largest and most functional fleet on the Black Sea), so Turkey's role in NATO has grown, not necessarily in a manner agreeable to Russian taste. However, it should also be noted, with the end of the cold war, NATO has been developed into some other platform, not very much responding to the security concerns of Turkey. Throughout the 1990s, Turkey has experienced undeclared arms embargoes from her Western allies, especially from Germany and the USA in different forms. For example, Germany has criticized the use of German weapons in the war against terror in South-eastern Turkey. On the other hand, the USA has refused to transfer any major military-technical technology to Turkey for most of the projects, especially the attack helicopter one. So, in the second half of the 1990s, Turkey has allied itself with Israel. Through this very important alliance, Turkey has achieved important modernization projects of the Turkish armed forces as well as considerable technology transfer. But the political message of this alliance was more important. Through this alliance, Turkey successfully imposed a huge pressure on Syria, the chief financier and supporter of Kurdish separatist terrorism in Turkey. As a result, Syrian authorities were forced to deport Öcalan at the end of the 1990s. From the 1990s until 2004 ${ }^{4}$ Turco-Israeli cooperation has not attracted any major reaction from Russia. On the other hand, from 1997 on, Israeli companies have taken an active role in adopting Russian arms to NATO standards, especially in avionics. At least that was the case in the Turkish bid for attack helicopters, and the Israeli-Russian project of Ka-521.

${ }^{1}$ B. Oran, Türk Dış Politikası: Kurtuluş Savaşından Bugüne Olgular, Belgeler, Yorumlar, Cilt I (1919-1980), İletişim Yayınları, İstanbul, 2001, pp. 155-177.

${ }^{2}$ S. Bilge, 'An analysis of Turkish-Russian relations', Perceptions, June-August 1997, p. 71.

${ }^{3}$ Note here: a convenient introduction to these themes is N. Stone, 'Turkey in the Russian mirror', in L. Erickson and M. Erickson (eds), Russia: War, Peace and Diplomacy, Weidenfeld \& Nicolson, London, 2005, pp. 86-101.

${ }^{4}$ Israel has started to export arms to Saakashvili regime from this year on. 
Although Turkey was a member of NATO during the cold war, her relations with the West were not problem-free. From 1964 onwards, from the Johnson letter of that year, the Soviet Union became the Mecca to be turned to, especially on matters related to the Cyprus crisis. With Soviet aid a good part of Turkish heavy industrial infrastructure was built between 1965 and 1980. The Soviet alternative was very important especially during the embargo years after the Cyprus war of $1974 .^{5}$

Turkey and Russia have a number of issues on which both countries have taken diametrically opposing views. For instance, Georgia has been included into the economic, cultural and military hinterland of Turkey since the early 1990s. The Georgian army trained by Turkish instructors, its economy surviving with transit reserves, etc. ${ }^{6}$ That was not pleasing Russians. Some other issues include(d) the Bosnia problem, Kosovar independence, Nagorno-Karabagh, territorial integrity of Georgia and some other former Soviet states.

Azerbaijan, for reasons of traditional ethnic, linguistic and cultural bonds, is almost required to have close relations with Turkey, and its oil and gas have already started to flow along the Baku-Tbilisi-Ceyhan crude oil pipeline. There is also a railway currently under construction from Kars to Baku via Tbilisi, bypassing Armenia. As the Georgian-Azerbaijani relationship with Armenia becomes difficult, there are obvious reasons for the Turkish-Russian relationship to reflect this. There are moreover very ugly problems: PKK terrorism for Ankara and Chechen terrorism for Moscow, which have made, and still might make, for complications in the Turco-Russian relationship.

There is an obvious economic perspective as well, the growth of trade and investment. Turkey has been emerging as a manufacturing centre of considerable weight in the global economy. Industrialization, to some degree a consequence of the displacement of German factories, is now reaching beyond the original heartlands in the west and north-west, and affects areas far into the interior, such as Adana, Gaziantep and Kayseri. Since 2001, the number of registered motor vehicles has increased by almost 50 per cent (from 7 to 10 million), industrial production is rising at an annual average of 8 per cent, the country's foreign trade volume has tripled and per capita electricity net consumption has risen by around 50 per cent. ${ }^{7}$

Turkey, to sustain growth, needs secure and affordable energy (and more efficient use of that). Russia in the last two decades has emerged as the primary energy supplier for Turkey. In return Turkey is paying its energy bill in world prices, in cash and on time. This is reflected in growing trade figures and has had a visible impact on the extent and content of the political relationship.

There have been several studies of this, emphasizing one aspect or another. Sezer (2001) highlights a certain contradiction, in that state relations have proceeded smoothly, on the basis of economic ties, whereas fear and distrust shape attitudes among the political elite. Torbakov (2005) thinks that diminishing security concerns, together with natural gas, will radically alter the bilateral

\footnotetext{
${ }^{5} \mathrm{M}$. C. Aslan, The Cyprus Question in the Making and the Attitude of the Soviet Union Towards the Cyprus Question (1960-1974), Bilkent University, Ankara, 2008, pp. 51-77.

'Saakashvili pulled the trigger: Turkey between Russia and Georgia', SETA Policy Brief, August 2008, available at the following website: < http://www.setav.org/document/Policy_Brief_No_20_ Hasan_Ali_Karasar.pdf $>$.

${ }^{7}$ Statistical Year Book, Turkish Statistical Institute, 2006, p. 195.
} 
relationship. Akturk (2006) ${ }^{8}$ stresses the convergence of the regional political agendas of the two countries, an outcome of the alteration in the power balance which developed in Turkey's favour in the 1990s. Hill and Taspinar (2006) even suggest that a common disillusionment over US policies in the Middle East, together with expanding trade, and cooperation over terrorism and the Black Sea are bringing Turkey and Russia closer. They do, however, refer to this as a 'strange coupling'. Jensen looks at the question of Putin's successors, sees faction-fighting among energy lobbies and reckons that Gazprom's increasing weight in Russian domestic politics will limit Turkey's ability to act as an energy hub. Akgun (2007) ${ }^{9}$ similarly points to the role of Gazprom as a pivot for Russian foreign policy and to the over-reliance of European countries on Russia as a primary energy supplier. In a recent study, Yarnik (2007) analyses the nature of renewed Turco-Russian cooperation and underlines the rising trust in security matters, the booming trade and Vladimir Putin's aim to give economic relations priority in Russian foreign policy. Winrow $(2004,2007)$ in similar ways analyses the impact of this closer relationship with Russia on Turkey's relations with NATO and the USA in the wider Black Sea region. He foresees closer energy ties between Ankara and Moscow and believes that this might complicate Turkey's relations with the USA and the European Union (EU). Thus, in all such analyses, the booming trade relations between the two nations emerge as a decisive factor, transforming what a leading commentator, Dmitri Trenin $(1997)^{10}$, called a 'schizophrenic' relationship.

The present study examines whether trade and energy considerations can bring about a real rapprochement between Russia and Turkey. In contrast to other analyses, it concludes that the future of Turkish-Russian cooperation does not necessarily lie in the field of energy. Today, we observe a temporary warming of political relations, one that depends on a variety of factors, some of which are themselves somewhat unstable. In a multi-polar setting, and given the fundamental interdependence that the natural gas trade involves, the two nations will of course continue to cooperate as and when their regional foreign-policy agendas converge. But energy policy in itself is more likely to cause problems.

This study has three main parts. The first section looks at the changing political and economic fundamentals of the 2000s. The second section analyses the trade and energy policies of the two countries in the political context. The third section considers how durable and strong a Russo-Turkish partnership may be in the future.

\section{Changing fundamentals of the political and economic context of the 2000s}

The end of the cold war is universally agreed to be the starting point in the new Russo-Turkish relationship. Ideological differences went by the board; the prevailing military confrontation was replaced by lesser ones (such as the Chechen conflict, or the clash between Armenia and Azerbaijan over NagornoKarabagh) in the 1990s. In a multi-polar world, it was likely that Russia and

\footnotetext{
${ }^{8}$ S. Akturk, 'Turkish-Russian Relations after the Cold War (1992-2002)', Turkish Studies, 7(3), September 2006, pp. 345-346, accessed at the EBSCO Host on 28 April 2009.

'S. Akgun, 'The Russian Federation as an energy supplier', Turkish Policy Quarterly, 6(2), Summer 2007, p. 29, accessed at the EBSCO Host on 28 April 2009.

${ }^{10} \mathrm{D}$. Trenin, 'Russia and Turkey: A cure for schizophrenia', Perceptions, Journal of International Affairs, 2(2), June-August 1997, p. 58, accessed at the EBSCO Host on 28 April 2009.
} 
Turkey, given the problems of their neighbourhood, would consider an overall understanding that would obviate the endless political troubles that took such attention and energy in the 1990s.

Another important and obvious consequence of the end of the cold war was the victory of liberal politico-economic thought over communism. The purport of this was that in the new world order social and economic strength, not military or ideological factors, would define spheres of influence. As Nye said (2004), love, contrary to Machiavelli, matters as much as fear: power would not rest on the number of nuclear warheads or on the global reach of military strength but on the ability of a state's culture, political values and foreign policies to change preferences in other states. ${ }^{11}$ Kissinger $^{12}$ (2001) also points to the changing nature of power in the post-cold war era, saying that 'Power has changed: Saudi Arabia has it without an army whereas the Soviet Union had it without an economy.'

But, beyond the ending of the cold war, other matters have affected RussoTurkish relations.

\section{Failed expectations of the 1990s}

Turkey's self-proclaimed role to fill the post-Soviet vacuum in parts of Eurasia was a failure. In the immediate aftermath of the Soviet collapse, Turkey aspired to help in the transition of the newly independent states of the Caucasus and Central Asia on the basis of the Turkish model. There were significant increases in cultural relations, student exchanges and high profile summits, but Turkey's financial weakness and her pre-occupation with internal economic and political problems, in particular political Islam and the PKK, played a decisive role in this failure. By the end of the 1990s, it was clear that Turkey was far from being a model. She lacked the resources to be a locomotive country. Stabilization of the limit and scope of Turkish penetration in the Caucasus and Central Asia had a relaxing effect on hostile Russian public opinion. ${ }^{13}$ Turkish foreign policy gradually adjusted to this reality and with the candidacy status endorsed in 2002, membership of the EU became Turkey's most important foreign-policy goal.

In similar vein, Russia's desire to retain its hegemonic role over the former Soviet space also failed in the 1990s. Many of the Eastern European countries were integrated into NATO and became members of the EU. Whereas in 1993 the Russian foreign-policy concept ${ }^{14}$ called for a unified military strategic space in the Commonwealth of Independent States (CIS), in 2000, the revised foreign-policy concept $^{15}$ gave Russian economic interests in the international arena priority. The new foreign-policy concept placed Russia in the multi-polar system of international relations, of shifting and sometimes conflicting interests, that is the

\footnotetext{
${ }^{11}$ J. Nye, Soft Power: The Means to Success in World Politics, Public Affairs, New York, 2004, pp. 4-6.

${ }^{12} \mathrm{H}$. Kissinger, The National Interest, No. 64, Summer 2001, p. 13.

${ }^{13}$ V. I. Danilov, 'Some features of Russian-Turkish relations in the 1990s', Perceptions, December 2001-February 2002, p. 18.

${ }^{14}$ The foreign policy concept is available at the following website: <http://countrystudies.us/ russia/77.htm $>$ accessed on 14 January 2008.

${ }^{15}$ The revised foreign policy concept is available at <http://www.fas.org/nuke/guide/russia/ doctrine/econcept.htm>, accessed on 14 January 2008.
} 
world's reality. Military power, yes of course, but an ever greater role would accrue to economic, political, scientific and technological, ecological and information factors.

Changing and converging regional foreign-policy agendas

US activism in the CIS and the Middle East has caused alarm in both Turkey and Russia.

In fact, Putin's reign marked a decisive shift in the foreign-policy choices of Russia, and a departure from the earlier idea of inevitable competition with the USA and the EU. Putin was willing to recognize the global leadership of the USA in return for Russia acquiring a special role within the old Soviet space. ${ }^{16}$ However, the USA, although exploiting Russian support in Afghanistan and Central Asia, was hesitant to conclude such a deal. The US and Russian rift deepened during the war on Iraq, during which Russia joined forces with the coalition of the unwilling, namely, France and Germany. Besides, the multicoloured revolutions in Ukraine ${ }^{17}$ and elsewhere, including Central Asia, dashed the foundations of Putin's US policy. ${ }^{18}$ They appeared as unwarranted intrusions.

Turkey was similarly disturbed by US military activism in Iraq. The decisive break in relations occurred in March 2003, when the Turkish parliament turned down the US request for opening a northern front in Iraq, via Turkish territory. Since then, US-Turkish political relations have worsened: the USA cooperated with the autonomous Kurdish region in Northern Iraq, which Ankara regarded with mistrust. ${ }^{19}$

Besides, Russo-Turkish cooperation in the Black Sea region also seems to be growing, given the apparent American eagerness to penetrate this area. In 2005, the USA attempted to join the Black Sea Economic Cooperation (BSEC) as an observer; this was stopped by joint Turco-Russian action. ${ }^{20}$ A second US attempt was made in 2006 to extend the NATO-led Operation Active Endeavor to the Black Sea, a proposal rejected, though for different reasons, by Russia and Turkey. The USA thereupon enlisted Romanian and Bulgarian support, establishing military bases covering the Black Sea. ${ }^{21}$

Another area of convergence is the foreign policy of the two countries towards Iran. ${ }^{22}$ Both Turkey and Russia have sought to maintain economic

${ }^{16}$ D. Trenin, 'Russia leaves the West', Foreign Affairs, 85(4), July-August 2006, p. 4, accessed at the EBSCO Host on 10 January 2008.

${ }^{17}$ British Helsinki Human Rights Group provides a forum for the few dissenting voices in the West on the Rose and Orange revolutions in Georgia and Ukraine. These are available at the following web addresses: 'Georgia 2003: the revolution of guns not roses', < http:/ / www.bhhrg.org/CountryReport. asp?CountryID=10\&ReportID=207\&keyword=Georgia $>$; 'Ukraine's clockwork Orange Revolution', < <ttp://www.bhhrg.org/CountryReport.asp?CountryID=22\&ReportID= $241 \&$ ChapterID $=737 \&$ next $=$ next\&keyword $=$ Ukraine $>$.

${ }^{18}$ D. Trenin, 'Russia leaves the West', Foreign Affairs, 85(4), July-August 2006, p. 4, accessed at the EBSCO Host on 10 January 2008.

${ }^{19}$ F. Hill and O. Taspinar, 'Turkey and Russia: axis of the excluded?', Survival, 48(1), Spring 2006, pp. 84-98.

${ }^{20 ، A B D}$ Karadenize Usleniyor', Radikal, 12 July 2005.

${ }^{21} \mathrm{~A}$. Cohen and I. Conway, 'US strategy in the Black Sea region', 13 December 2006, available at the following website: < http://www.heritage.org/Research/RussiaandEurasia/bg1990.cfm>.

${ }^{22}$ I. Torbakov, 'Turkey and post-Soviet Eurasia: seeking a regional power status', Insight Turkey, 7(2), April-June 2005, p. 121. 
relations with Iran despite US pressure to sever ties. Turkey wishes to sell Iranian gas to Europe via the Nabucco pipeline and reached an understanding in August 2007 to develop the South Pars natural gas fields (Persian Gulf); Russia has been selling military technology and civilian nuclear capability to Iran.

\section{Domestic stability and leadership change}

After the troubled decade in office of Boris Yeltsin, the Russian presidency passed in 2000 to Vladimir Putin, already Prime Minister. His election manifesto made three major promises to the Russian electorate: a decent life, a strong state and the rule of law, which were what Russians most needed after that decade of traumatic social and economic transition. Putin also explicitly linked Russia's world role and the condition of her economy. ${ }^{23}$

Russia, her finances in hopeless disarray in 1998 due to a decade of collapse, plundering, corruption and money flight, entered upon a period of sustained growth during the Putin years, thanks to realistic macro-economic planning, to a tightening of fiscal policies and most importantly to climbing oil and gas prices. With the new wealth Putin was able to strengthen his domestic position in various ways. First of all, he reversed the growing tide of federalization which Yeltsin had allowed and used for electoral support. He cracked down on Chechnya, the oligarchs and any aspiring political opposition and unified the country around his leadership. ${ }^{24}$

Similar changes took place in Turkey after the 2002 elections. The Turkish electorate, weary of long years of unsatisfactory economic performance, and suffering from a severely fragmented political scene, voted for a single party government, the Justice and Development Party, led by Recep Tayyip Erdoğan.

Erdoğan, liberal in his economic and foreign policy, and, to begin with, unsure of his party's likely popularity, did not have any alternative to the economic reform package that had been formulated and agreed with the IMF during the previous government. Political stability has greatly helped economic improvement and Erdoğan has even been able to proceed with the long delayed reforms required for membership of the EU. Erdoğan's primary message to the electorate was similar to Putin's: a better life and a stronger Turkey in the international arena. Economic prosperity occupied an important place on Erdoğan's agenda. ${ }^{25}$

The evident shift in the foreign policy of both countries came from a recognition that regional power would come from prosperity that clearly depended on cooperation. Strong leadership that is in favour of a functioning market economy mattered.

\footnotetext{
${ }^{23}$ An assessment of the manifesto can be found at: < http://news.bbc.co.uk/1/hi/world/europe/ 604352.stm>.

${ }^{24} \mathrm{M}$. Freedman and H. Brown, 'Energy Tsar; Vladimir Putin is using Gazprom, and its monster reserves, to remake Russia. Should you own a piece of it?', Forbes, 178(2), 2006, accessed at the EBSCO Host on 16 February 2008.

${ }^{25}$ You can review some themes from Erdoğan's speeches at the following websites: $<$ http: / www. akparti.org.tr/hukumetprg.doc $>$; < http://www.economist.com/world/europe/displaystory. cfm?story_id=9535158> ; < http://global.factiva.com/ha/default.aspx?ftx=Turkey $\% 20$ and $\% 20$ Erdogan $>$.
} 


\section{Military threat perceptions}

Another noteworthy change concerned military threat perceptions. Throughout the 1990s, Turkey desired the removal of Russian military bases in the South Caucasus that could be used to de-stabilize Turkey's neighbours. Turkey even faced outright threats from Russia when she was on the brink of intervening in the war between Armenia and Azerbaijan over Nagorno-Karabagh. ${ }^{26}$ All these fears were dissipated by the turn of the millennium. Cooperation followed.

In 2001, the Black Shore littoral states, a Turkish initiative, established BLACKSEAFOR in Istanbul. A multi-national search and rescue initiative was followed by Operation Black Sea Harmony which was intended specifically to deter terrorist activities in the Black Sea. ${ }^{27}$

In January 2002, the Russian Chief of Staff, Anatoly Kvashnin, visited Turkey and a military cooperation treaty was signed in which both states agreed to put down the operations of terrorist organizations in their respective territories that could threaten the other. Lists of suspects were exchanged in an effort to crack down on the illegal activities of pro-Chechen and pro-Kurdish organizations. At the same time, the Turkish Chief of Staff declared that the Russian presence in the Southern Caucasus was no longer considered a threat. ${ }^{28}$

\section{The search for energy security, environmentalism and the rise of natural gas}

Rising global oil demand, concern over the adequacy, reliability and pricing (costs) of energy supplies, and the associated environmental implications (greenhouse gas emissions) occupy the state and business agendas of developed and developing countries alike. States face an increasingly challenging and complex set of trade-offs in their quest for energy security. ${ }^{29}$

In the last two decades, natural gas has been widely introduced as a substitute for the oil used in industrial consumption. It is cheaper and environmentally less hazardous. The share of natural gas in total world energy consumption is forecast to climb from the current 23 per cent to 28 per cent by 2025 . The recent EU attempt to liberalize the electricity and natural gas markets may marginally increase the use of natural gas for industrial and household consumption. ${ }^{30}$

However, the market structure for natural gas is very different from crude oil because it is very expensive and difficult to transport. LNG (liquefied natural gas) provides an option for shipping but even that requires a complex supply chain

\footnotetext{
${ }^{26}$ D. Sezer, 'Turkish-Russian relations a decade later: from adversity to managed competition', Perceptions, March-May 2001, pp. 79-98; D. Sezer, 'Turkish-Russian relations: the challenges of reconciling geopolitical competition with economic partnership', Turkish Studies, 1(1), Spring 2000, p. 66.

${ }^{27}$ For further details of the range of BLACKSEAFOR activities you can visit the website: $<$ http:// www.blackseafor.org/Kurulus_Ana.asp $>$.

${ }^{28} \mathrm{G}$. Singh, 'Russian bear calls on gray wolf', The Asian Times, accessible at the following website: < http://www.atimes.com/atimes/Central_Asia/FH28Ag01.html>, accessed on 8 January 2008; I. Torbakov, 'A new security arrangement takes shape in the South Caucasus', accessible at the following website: <http://www.axisglobe.com/article.asp?article=71>, accessed on 8 January 2008.

${ }^{29}$ F. Verrastro and S. Ladislaw, 'Providing energy security in an interdependent world', The Washington Quarterly, 30(4), Autumn 2007, p. 95.

${ }^{30}$ 'The future of gas: will really meet expectation'. Study Paper prepared for the Clingendael International Energy Programme, pp. 5-6.
} 
which adds significantly to the costs of transport. Therefore, without a given market and long-term contract, marketing of natural gas is almost impossible. The whole chain of supply forces suppliers and consumers into a long-term mutual relationship of dependence. For the supplier, the demand is crucial to invest in field development and transport facilities. On the demand side, in order to mitigate technical or political risks the consumers pursue policies that primarily consist of a healthy energy balance and diversification of energy sources. ${ }^{31}$

The changing features of the energy market are also significant for the Turkish-Russian relationship from both demand and supply side. Russia possesses the globe's largest natural gas reserves. In Turkey, while natural gas consumption has boomed, the use of alternative fuels, diversification of resources and energy conservation has become a top priority issue for energy policy. The Russian Federation emerged as the primary supplier to Turkey of natural gas and to a lesser extent of crude oil and coal. But the search for alternatives is vigorous.

\section{Trade and energy: primary drivers?}

Trade

The fall of the Soviet Union in 1991 was followed by a terrible collapse of the Russian economy, especially with the introduction of Gaidar's reform programme, which is well remembered as 'shock therapy'. The Russian economy passed through a long and wrenching period of depression. According to the official Russian statistics from 1990 to the end of 1995 the Russian GDP declined by roughly 50 per cent. Many industries were drained of investment funds and had to cease operations. ${ }^{32}$

At the initial stages of the crisis even basic consumer goods disappeared from the market. The Russian industrial collapse went hand in hand with a booming shuttle trade from Turkey. The shuttle trade owed its resilience to the deep impact it had on the Russian economy and its golden days lasted until the late 1990s. It provided many employment opportunities to low-income Russians, effectively delivering a flood of cheap goods to financially depressed Russian consumers. Russian legislation was arranged favourably to encourage such trade, granting many tax exemptions. ${ }^{33}$

In the second half of the 1990s, particularly towards the end, shuttle trade with Turkey started losing its initial vigour. This was because, first of all, competing supplier markets emerged and started carving up the Turkish place in the Russian markets. The most noticeable impact was from China and the United Arab Emirates. Then with the looming crisis in August 1998, the purchasing power of Russians decreased significantly. Lastly, but probably the most decisive factor, upon the insistence of the IMF, the Russian Federation changed the customs legislation to limit the amount of shuttle trade. Currently, it is estimated to have stabilized at around $\$ 2-4$ billion annually. ${ }^{34}$

\footnotetext{
${ }^{31}$ Ibid., p. 8.

${ }^{32}$ D. E. Hoffman, The Oligarchs: Wealth and Power in the New Russia, Public Affairs, New York, 2003, pp. 178-208.

${ }^{33}$ M. Ellman, 'The Russian economy under El'tsin', Europe-Asia Studies, 52(8), December 2000, p. 1418. For an assessment of the shuttle trade figures and prospects, visit: < http:/ / www.rusyaofisi. com $/$ kargo.htm $>$.

${ }^{34}$ H. Selcuk, Turkiye-Rusya Ekonomik Iliskileri, Iletisim Yayinlari, Istanbul, 2005, pp. 60-64.
} 
With the rejuvenation of Russian industrial performance, it would be naive to expect the shuttle trade to have a bright future. The World Trade Organization negotiations with Russia and the determination of the Russian authorities to end the unregistered economy dealt a heavy blow to the prospects of the shuttle trade. The controls at the border points continue to be stricter and legislative loops are being filled in recent years. The volume of shuttle trade is most likely to retreat to negligible levels by $2015 .^{35}$

Another issue worth noting is the performance of the Turkish construction sector in Russia and the booming tourism. The Turkish construction sector placed itself strategically in Russia before the break up of the USSR thanks to the terms of the first gas sales agreement. Turkish construction contractors, since the early 1990s, have completed various projects in Russia totalling $\$ 20$ billion, one-fifth of this amount during the late Soviet period. ${ }^{36}$ There are good prospects in the construction sector as the infrastructure and housing needs in Russia will continue to grow and require $\$ 360$ billion worth of investment in the next decade. $^{37}$

However, this is a sector where the Turkish contractors have increasingly started to face tough competition from Eastern European and Chinese contractors. According to the statistics provided by the Russian Construction Platform the revenues have stabilized at around $\$ 2.5$ billion annually. ${ }^{38}$ It will require a great effort to protect even those levels in the near future.

Tourism is another area where the number of visitors, in particular from Russia, has grown considerably in the last decade. Russian tourists are second only to Germans in numbers. Starting from 0.6 million in 1996, the number of Russian visitors reached 2 million in 2007. Turkey each year on average attracts 10 per cent of all Russian tourists, but the statistics show that the Far East has been taking a larger chunk of the marginal demand from Russia. According to TurkStat, 2 million Russian tourists generated revenue of roughly $\$ 1.4$ billion in 2007.39

The volume of trade between Russia and Turkey throughout the 1990s, outlined in Table 1, remained relatively stable.

The trade volume reached unprecedented, and maybe even unpredicted, levels in the first of decade of the 21st century. Growing volumes of exports combined with soaring prices of energy sales seem to be the driving force behind the shining trade data.

In 2006, Russia delivered nearly 20 billion cubic metres (bcm) of natural gas to Turkey. This amount represented a 50-fold increase in volume since the start of the natural gas trade in 1987. It is exactly two-thirds of the total Turkish natural gas consumption today. ${ }^{40}$ Add to this Turkey's annual average imports of around

\footnotetext{
${ }^{35}$ For an estimate on the shuttle trade you can visit the website: <http://www.rusyaofisi.com/ kargo.htm>.

${ }^{36} \mathrm{H}$. Güneş, 'İnşaatta Türklerin küresel rekabeti', Milliyet, 6 December 2007.

37'İnşaatçılarımızın Rusya'daki geleceği', interview with Turkish Trade Attaché to Moscow Bahri Can Çalıcıŏglu, available at: <http://www.insaat.ru/content/view/113/28/> .

${ }^{38}$ The summary table providing the volume of works completed by Turkish contractors in Russia is provided on the following website: < http://www.insaat.ru/content/view/94/34/>.

${ }^{39}$ Statistical Year Book, Turkish Statistical Institute, 2006, p. 166.

${ }^{40} \mathrm{~A}$ good overview of the natural gas trade statistics can be found on the following website: < http://www.botas.gov.tr/eng/activities/ng_ttt.asp>, accessed on 13 January 2008.
} 
Table 1. Bilateral trade data (US\$ million) ${ }^{\mathrm{a}}$

\begin{tabular}{|c|c|c|c|c|c|c|c|c|}
\hline Year & $\begin{array}{c}\text { Exports } \\
\text { from } \\
\text { Turkey }\end{array}$ & $\begin{array}{c}\text { Share in } \\
\text { overall } \\
\text { Turkish } \\
\text { exports } \\
(\%)\end{array}$ & $\begin{array}{c}\text { Share in } \\
\text { overall } \\
\text { Russian } \\
\text { imports } \\
(\%)\end{array}$ & $\begin{array}{c}\text { Imports } \\
\text { to Turkey }\end{array}$ & $\begin{array}{c}\text { Share in } \\
\text { overall } \\
\text { Turkish } \\
\text { imports } \\
(\%)\end{array}$ & $\begin{array}{c}\text { Share in } \\
\text { overall } \\
\text { Russian } \\
\text { exports } \\
(\%)\end{array}$ & Balance & Volume \\
\hline 1992 & 438.4 & & & 1040 & & & -601 & 1478 \\
\hline 1993 & 499 & & & 1542 & & & -1043 & 2041 \\
\hline 1994 & 820.1 & & & 1045 & & & -225 & 1865 \\
\hline 1995 & 1238.2 & & & 2082 & & & -844 & 3320 \\
\hline 1996 & 1494 & 6.43 & 2.19 & 1900 & 4.35 & 2.10 & -407 & 3394 \\
\hline 1997 & 2056 & 7.83 & 2.86 & 2174 & 4.47 & 2.50 & -118 & 4230 \\
\hline 1998 & 1348 & 4.99 & 2.32 & 2152 & 4.69 & 2.89 & -804 & 3500 \\
\hline 1999 & 589 & 2.21 & 1.49 & 2374 & 5.83 & 3.14 & -1785 & 2963 \\
\hline
\end{tabular}

${ }^{\mathrm{a}}$ Data provided by the Foreign Trade Centre of Turkey.

15-20 per cent of crude oil needs (on a range of 4-6 million tonnes), ${ }^{41}$ the energy invoice from Russia reached roughly $\$ 9$ billion, almost half of the bilateral trade volume, which was about $\$ 20.7$ billion in 2006 . In 2007 , the Russian energy bill is estimated at about $\$ 12$ billion. ${ }^{42}$

If we look into the details of the trade data in 2006 we may understand the degree of interdependence better. The share of imports from Russia is almost 13 per cent of overall Turkish imports, marking Turkey's largest imports from any single country, followed by 11 per cent from Germany. This amount is 6 per cent of total Russian exports. Turkish exports to Russia constitute around 2 per cent of total Russian imports. Turkey's exports to Russia, although at historic heights, constitute only 3.7 per cent of its total exports, with an annual \$3226 million in 2006. The bilateral trade data should be seen in the light of Turkey's overall trade balance. In 2006, overall Turkish exports were $\$ 85$ billion and overall imports were $\$ 137$ billion. Table 2 provides an overview of the trade situation. ${ }^{43}$

The figures in 2006 show that Russia has not become a significant export market for Turkish goods. Although in absolute terms the volume of trade has grown significantly, in relative terms Russia's value as an export market decreased slightly. The value of Turkish exports to Russia is comparable to those to Spain or Iraq. ${ }^{44}$ For Russia, however, Turkey has acquired its place in the top ranks as a significant export market, comparable to Germany or Italy in volume. Its importance and share will increase in view of the energy prices and the Turkish lust for energy.

\footnotetext{
${ }^{41}$ The information on energy balance of Turkey can be reached at: < http://www.epdk.gov.tr/ lisans/petrol/petrolbilgisistemi/tupras/ek6.htm>, accessed on 16 January 2008.

${ }^{42}$ Author's personal communication with the State Pipeline Corporation and the Ministry of Energy and Natural Resources of Turkey, 11 January 2008.

${ }^{43}$ Data provided by the Foreign Trade Centre of Turkey has been jointly used by the information available on the following website: <http://www.cbr.ru/eng/statistics/credit_statistics/print. asp?file=bal_of_paym_an_06_e.htm > .

${ }^{44}$ The data is available on the Undersecretariat for Foreign Trade website: $<$ http:/ / www.dtm.gov. $\mathrm{tr} / \mathrm{dtm} w e b /$ index.cfm?action $=$ detayrk\&yayinID $=1116 \&$ icerikID $=1225 \&$ dil $=\mathrm{TR}>$, accessed on 28 December 2007.
} 
Table 2. Bilateral trade data (US\$ million) ${ }^{\mathrm{a}}$

\begin{tabular}{|c|c|c|c|c|c|c|c|c|}
\hline Year & $\begin{array}{l}\text { Exports } \\
\text { from } \\
\text { Turkey }\end{array}$ & $\begin{array}{c}\text { Share in } \\
\text { overall } \\
\text { Turkish } \\
\text { exports } \\
(\%)\end{array}$ & $\begin{array}{c}\text { Share in } \\
\text { overall } \\
\text { Russian } \\
\text { imports } \\
(\%)\end{array}$ & $\begin{array}{l}\text { Imports } \\
\text { to Turkey }\end{array}$ & $\begin{array}{c}\text { Share in } \\
\text { overall } \\
\text { Turkish } \\
\text { imports } \\
(\%)\end{array}$ & $\begin{array}{c}\text { Share in } \\
\text { overall } \\
\text { Russian } \\
\text { exports } \\
(\%)\end{array}$ & Balance & Volume \\
\hline 2000 & 644 & 2.30 & 1.43 & 3887 & 7.16 & 3.70 & -3243 & 4531 \\
\hline 2001 & 923 & 3.00 & 1.72 & 3436 & 8.60 & 3.38 & -2513 & 4359 \\
\hline 2002 & 1168 & 3.32 & 1.92 & 3863 & 7.58 & 3.63 & -2695 & 5031 \\
\hline 2003 & 1363 & 2.90 & 1.82 & 5420 & 7.88 & 4.03 & -4057 & 6783 \\
\hline 2004 & 1851 & 2.94 & 1.92 & 9009 & 9.27 & 4.92 & -7158 & 10,860 \\
\hline 2005 & 2377 & 3.2 & 1.8 & 12,906 & 11.02 & 5.02 & $-10,529$ & 15,283 \\
\hline 2006 & 3226 & 3.7 & 1.92 & 17,494 & 12.7 & 5.89 & $-14,268$ & 20,720 \\
\hline $\begin{array}{l}2007 \\
\text { (Jan- } \\
\text { Oct) }\end{array}$ & 3824 & 4.4 & & 18,603 & 13.6 & & $-14,779$ & 22,427 \\
\hline
\end{tabular}

${ }^{a}$ Russia country profile, report prepared by Undersecretariat for Foreign Trade, DG Agreements.

We can draw the conclusion that Russo-Turkish trade relations will deepen but not to the advantage of Turkey. Turkey's dependence on Russia for energy resources, via contracts and pipelines, cannot be easily reversed, while the bill to be paid continues to soar. This fact has not gone unnoticed in Turkey and the search for other and preferably cheaper alternatives, and suppliers, is full steam ahead, including mobilization of alternative (hydro, wind, solar) and nuclear energy resources. ${ }^{45}$ Turkey announced its plans to build a nuclear power plant in the second half of $2008 .^{46}$

Moreover, it remains a question how symmetrically the strategic dependence created by the natural gas trade affects political relations. In a theoretical case of serious political crisis, Russia, with current energy prices, may well absorb the impact of a failed Blue Stream investment or a 1-2 per cent decrease in its export revenues. The only visible consequence could be the damage inflicted on its reputation as a reliable supplier. However, in such a situation Turkish industry and citizens are bound to face a deep energy shock. So while it is true that energy trade is adding more zeros to the trade figures, it is disputable, how such a trade relationship can be the foundation of a better political relationship. If the closer political relationship is a result of growing trade then the argument can be that Turkey, in anticipation of severe consequences, has decided to cooperate with Russia. The fundamental driver of Turkish-Russian relations seems to be something else, not easily explained by the trade inter-dependence.

Lastly, the trade figures, rather than indicating a developing partnership, indeed, may point to a future bottleneck and competition. Turkey's search for new and cheaper energy supplies has already triggered a managed competition with respect to new pipeline routes. The growing Turkish and European demand for energy in the next decade will be the decisive factor in determining the future energy transport routes. Turkey's strategic interest in becoming an energy hub and transit country clashes with Russian interests.

\footnotetext{
${ }^{45}$ A. Demirbaş, 'Turkey's renewable energy policy', Energy Sources, Part A, 2006, p. 662.

${ }^{46}$ Prime Minister Erdoğan's assessment of Government Action Plan on NTV, 10 January 2008.
} 
Energy

Immediately after the collapse of the Soviet Union, Russia faced serious problems on the resource development front. The sources of financing for the industry, pouring at an accelerated rate in the 1980s, vanished. There was simply no money around, not even to conduct the simplest field maintenance operations. The oil sector, whose costs of production rose steadily after the end of 1970s, and desperately in need of investment, found itself in a protracted crisis that resulted in a massive decrease in output, halved from 600 million tonnes in less than five years. Gas production, flat at more or less $500 \mathrm{bcm}$, was not hit as severely by investment cuts but suffered from non-payments from domestic customers. Exports were the only reasonable activity to generate profits for an ailing industry. ${ }^{47}$

Another complicating factor for the Russian oil and gas industry was the new political map emerging after the break up of the Soviet Union, which led to new transit relations. These routes were secure and granted during Soviet times. The very same routes emerged as potential bottlenecks and in some cases overt security problems for Russia. Byelorussia, Ukraine and the Baltic States on the immediate Western borders as well as Romania, Hungary and Poland on the Western routes moved from being constituent republics or orbit states to new jurisdictions which would have to be dealt with. ${ }^{48}$

An associated issue was the shift of markets for Russia. Throughout the 1990s, Russian exports to international markets beyond the former USSR steadily increased, while those to former Soviet republics contracted dramatically. As higher volumes had to be transported westward, a much larger proportion of the oil exports were directed to Russia's major port on the Black Sea, Novorossiysk. With the changing export destinations, the Russian oil industry also faced infrastructural capacity shortages in the 1990s, particularly oil export terminals. ${ }^{49}$

The change in export routes meant that ever increasing numbers of oil and LNG tankers had to cross the Turkish straits. When Turkey, quite reasonably, decided to stiffen the safety measures, it had an impact on the rate of passage. Although the Montreux Convention of 1936 guarantees the innocent passage rights to all parties, increasing tanker traffic in the Bosphorus has forced Turkish authorities to take some extra measures unilaterally. This aimed to slow down the tanker traffic with time and quality of passage limitations. One can easily see hundreds of oil tankers waiting at both ends of the Bosphorus, for their turn to be granted passage right.

Russian oil exporters had to search for new export routes and means, which triggered a struggle for more economical and secure export routes. ${ }^{50}$ The competitive struggle not only included Russia but all former Soviet states that were endowed with hydrocarbon riches, particularly the Caspian states such as Azerbaijan, Kazakhstan and Turkmenistan. Moreover, the transit countries

\footnotetext{
${ }^{47}$ J. D. Grace, Russian Oil Supply: Performance and Prospects, Oxford University Press, New York, 2005, p. 88.

${ }^{48}$ 'Energy policies of the Russian Federation', IEA Report, July 1995, counter-signed by the Russian Government as a part of Joint Declaration of Co-operation, p. 175.

${ }^{49}$ Ibid., p. 179

${ }^{50}$ N. Pamir, 'Enerji Arz Güvenliği ve Türkiye', Stratejik Analiz, p. 22.
} 
like Poland, Ukraine, ${ }^{51}$ Romania and Bulgaria (and even Greece) had a role to play in pipeline politics. ${ }^{52}$

Russia, in search of political leverage and higher profits, aspired to control the resource flows out of competing markets, namely, the Caspian. On the other side, Turkey, in association with the USA, tried to divert oil and gas resource flows from Russia. This was considered to provide an effective means of breaking the Russian economic and political domination in the region. As a part of this policy, Turkey pursued a dynamic role in development of the Baku-Tbilisi-Ceyhan (BTC) crude oil pipeline as the main export pipeline from the Caspian region. ${ }^{53}$

In any investment decision, political stability and security play a pivotal role and pipelines are no exception. Although many other political explanations can be provided, the conflict in Georgia (i.e. South Ossetia, Javakheti, Abkhazia) or in Dagestan and Chechnya obviously affected the planning of pipelines in the region. The northern Caucasus routes through Dagestan looked like a war zone and not worth investing in. Similarly, in the early 1990s PKK terrorism peaked in Turkey, an issue that was consistently used against the construction of the BTC pipeline. Both states, in expectation of gaining an advantage in the pipeline race, turned a blind eye to dissident elements in each other's territory. ${ }^{54}$

The first round of the game, mostly related to crude oil, was over when the BTC pipeline successfully became operational in 2006 with a capacity of 50 million tonnes per annum. In turn the Russian-backed Tengiz-Novorossiysk pipeline (Caspian Pipeline Consortium) was also operational as of 2003, with a crude oil transportation capacity of 22 million tonnes per annum (eventually reaching up to 67 million tonnes). The pipeline derby, on deciding the main export pipelines out of the Caspian region, was settled. ${ }^{55}$

With the development of more oil and gas resources in the Caspian region, future rounds in the game will be on expansion of existing export capacities and development of new routes. In this respect, the Kashagan oil field (off-shore Kazakhstan), developed by a consortium led by the Italian giant ENI, ${ }^{56}$ will play an important role. The prospects of this field, 1.2 million barrels per day in 2015, have already initiated a new search for routes that bypass the Turkish straits. The recent Russian activism on the Burgas-Alexandroupolis

\footnotetext{
${ }^{51}$ M. M. Balmaceda, 'Gas, oil and the linkages between domestic and foreign policies: the case of Ukraine', Europe-Asia Studies, 50(2), March 1998, p. 258.

${ }^{52} \mathrm{G}$. Winrow, 'Turkey and the east-west gas transportation corridor', Turkish Studies, 5(2), Summer 2004, pp. 23-42.

${ }^{53} \mathrm{~F}$. Hill, 'Seismic shifts in Eurasia: the changing relationship between Turkey and Russia and its implications for the South Caucasus', Journal of Southeast European and Black Sea Studies, 3(3), September 2003, p. 64.

${ }^{54} \mathrm{D}$. Sezer, 'Turkish-Russian relations a decade later: from adversity to managed competition', Perceptions: Journal of International Affairs, 6(1), March-May 2001, p. 82.

${ }^{55}$ Further details of projects are available on the following websites: for the Caspian Pipeline Consortium <http://www.cpc.ru/>; for the BTC < http://www.bp.com/genericarticle. do? categoryId $=9006669 \&$ contentId $=7014358>$.

${ }^{56}$ In January 2008, ENI agreed to sell an 8.5 per cent stake to KazakMunaiGaz for $\$ 1.78$ billion and to pay additional royalties in the range of \$2.5-4.5 billion. ENI will become co-operator along with ExxonMobil, Sheel and Total after 2011, the estimated date of first production. Business Week, Issue 4068, 28 January 2008.
} 
pipeline and Turkish preference for the Samsun-Ceyhan should be seen in this framework. ${ }^{57}$

In 2007, Russia signed a deal with Bulgaria and Greece to construct the Trans-Balkan Pipeline (Burgas in Bulgaria to Alexandroupolis in Greece) to provide an opportunity to carry more volumes of crude oil while bypassing the Turkish straits. After the deal, it remained a question mark how the Samsun-Ceyhan (a pipeline connecting the Black Sea to the existing oil terminal in the Mediterranean) crude oil pipeline, Turkey's preferred option for bypassing the straits, was going to have a sufficient amount of crude to justify the investment. ${ }^{58}$

Regarding natural gas, Russia's formidable giant Gazprom, though still a monopoly and inefficient, provides most of the gas to former Soviet states, to central Europe, as well as 25 per cent of the needs of Western Europe. Since the management change in 2001, when Putin's aide Alexei Miller took over, the profit of Gazprom increased from $\$ 440$ million to $\$ 7.5$ billion, on an annual turnover of $\$ 42$ billion. In a decade, its market value is expected reach $\$ 1$ trillion. ${ }^{59}$

Gazprom is a joint-stock company but during Putin's era it has become an arm of the state policy. The Russian elite, and in particular Putin, recognize the importance of the natural gas industry, which provides both subsidized gas to the nation and as much as 20 per cent of ( $\$ 77$ billion) its annual tax revenue. Oil and gas together account for 60 per cent of Russian export revenues ( $\$ 180$ billion) whereas all raw materials and semi-finished materials make up 80 per cent of all export revenues ( $\$ 240$ billion). ${ }^{60}$

Gazprom has been very aggressive and is committed to increasing its exports rapidly in the next decade. It has been very active in Europe, developing many partnerships in Germany, France and Austria. It announced deals with Japan, Iran and even China. By the end of next decade it expects to send LNG from reserves near the Barents Sea to ports in the USA. It cleverly played on the booming natural gas demand and energy security concerns of Turkey and proposed a direct pipeline link, avoiding any transit country, between Turkey and Russia, the Blue Stream. In partnership with ENI, Gazprom invested around $\$ 4$ billion, in the $1213 \mathrm{~km}$ natural gas pipeline (NGPL) project connecting Russia to Turkey underneath the Black Sea. ${ }^{61}$

The controversy is that, despite the ambitious marketing attack, Gazprom's output in the best case scenario may rise modestly in view of the decline in the

\footnotetext{
${ }^{57}$ J. Gorvett, 'Pipeline, pipeline, who's got the pipeline? Turkey's quest for energy significance', Washington Report on Middle East Affairs, 26(8), November 2007, accessed at the EBSCO Host on 12 January 2008.

${ }^{58}$ 'Samsun-Ceyhan'da Ilk Kazma Bugün', Radikal, 24 April 2007, available at the website: $<$ http:/ / www.radikal.com.tr/haber.php?haberno=21925>.

${ }^{59}$ M. Freedman and H. Brown, 'Energy Tsar; Vladimir Putin is using Gazprom, and its monster reserves, to remake Russia. Should you own a piece of it?', Forbes, 178(2), 2006 accessed at the EBSCO Host on 16 February 2008.

${ }^{60} \mathrm{P}$. Oppenheimer and S. Maslichenko, 'Energy and the economy: an introduction', in M. Ellman (ed.), Russia's Oil and Natural Gas: Bonanza or Curse, Anthem Press, New York, 2006, pp. 15-23. For more information see the World Bank's statistics, available at the following website: <http:// siteresources.worldbank.org/INTRUSSIANFEDERATION/Resources/macromay2006.pdf>; see also the Russian Central Bank statistics which are available at: < http://www.cbr.ru/eng/ statistics/credit_statistics/bp_2006_e.pdf>.

${ }^{61}$ J. P. Stern, The Future of Russian Gas and Gazprom, Oxford University Press, New York, pp. 24-25.
} 
giant Urengoi, Yamburg and Medvezhe natural gas fields. ${ }^{62}$ The Russian gas sector, monopolistic in structure and heavily regulated by subsidized prices, can only with difficulty deliver future output and export growth. ${ }^{63}$ The decline can be off-set either by developing greenfield projects or by non-Gazprom sources of supply, both within Russia and abroad, a fact increasingly recognized even in the official government projections. In this respect, the supply of Central Asian gas under agreements concluded with Kazakhstan, Uzbekistan and Turkmenistan are crucial. ${ }^{64}$ In late 2007, the Russian Federation unveiled a new NGPL that will carry Turkmen and Uzbek gas to the West. ${ }^{65}$

Turkey could have been content with Russia as its primary supplier. However, the Turkish economy, since its resurgence in 2001, has suffered the effects of increasing oil prices. The price of natural gas quadrupled (from 7.62 cents $/ \mathrm{cm}^{3}$ in 2000 to around 38 cents $/ \mathrm{cm}^{3}$ in 2007). The high natural gas prices had an effect on electricity prices, created inflationary pressure and led to ever widening current account deficit for the country. In the last days of 2007, electricity prices had to be increased by 19 per cent. The Turkish willingness to tackle the rising natural gas prices is evident in the recent rush for mobilizing alternative resources (build-operate type hydro-electric power dams and bio-diesel) and determination to build nuclear power generation capability.

Turkey also accelerated its efforts to become an energy transit country as well as an energy hub for the region. Turkey's energy transit strategy largely depends on availability of oil and gas resources to fill the lines and feasible investment schemes to attract grand scale international financing from investors, not to mention the required political dynamism to steer the project development stage. At the moment, Turkey seems in part to have all of the prerequisites to facilitate these investments. Also with current energy prices, Turkey's prospects for becoming a transit country are better. Higher prices shorten pay back periods and justify costly construction projects. ${ }^{66}$

There are five important projects constituting the core of Turkish transit strategy, two crude oil pipelines and three NGPLs. The essence of the strategy is to reach and carry, initially, the Caspian and eventually the Middle Eastern hydrocarbons to the European markets.

The crude oil pipelines, namely, Baku-Tbilisi-Ceyhan and Samsun-Ceyhan, are destined to reach the Turkish town of Ceyhan on the Mediterranean, which has already become an international oil terminal with a storage capacity of around 2 million tonnes of crude oil and two loading jetties. The BTC crude oil pipeline became operational in May 2006. The development of Samsun-Ceyhan project is in progress.

\footnotetext{
${ }^{62}$ V. Milov, 'Russian energy sector and its international implication'. Discussion Paper prepared for the Institute of Energy Policy, pp. 10-14.

${ }^{63} \mathrm{R}$. Ahrend, 'Sustaining growth in a hydrocarbon based economy', in M. Ellman (ed.), Russia's Oil and Natural Gas: Bonanza or Curse, Anthem Press, New York, 2006, pp. 112-114.

${ }^{64} \mathrm{R}$. Ahrend and W. Tompson, 'Unnatural monopoly: the endless wait for gas sector reform in Russia', Europe-Asia Studies, 57(6), September 2005, pp. 805-807.

${ }^{65}$ 'Russia to sign Turkmenistan pipeline deal soon', New York Times, 23 November 2007, available at $<$ http://www.cnbc.com/id/21935750>.

${ }^{66} \mathrm{C}$. Pala, 'Turkey as an energy bridge between east and west', Insight Turkey, 7(4), October-December 2005, pp. 36-37.
} 
The NGPLs are Nabucco, the Turkey-Greece-Italy interconnector (TGI) and the Shah Deniz. The Shah Deniz pipeline was commissioned in July 2007. This has already given an opening to Azeri and Turkmen gas. ${ }^{67}$ The technical capacity of the Shah Deniz Pipeline, 42 inch, is sufficient to handle up to $17 \mathrm{bcm}$ of deliveries and can be easily expanded for larger volumes. The Turkey-Greece interconnector pipeline, though smaller in volume, became operational in 2007.

The Nabucco pipeline is the centrepiece of the natural gas transit strategy, a trunk line starting in the eastern Turkish city of Erzurum and stretching around $4000 \mathrm{~km}$ to Austria, crossing en route Bulgaria, Romania and Hungary. The technical capacity of the pipeline is $31 \mathrm{bcm}$ per year. Recently, there have been many positive developments in favour of the project. Germany's energy giant RWE has formally participated in the project. In addition Turkey came forward with some alternative investment scenarios to shorten the route and downsize the required investment. ${ }^{68}$

However, there are also many challenges ahead. Whereas Gas de France has shown interest to participate in the project, the Turkish government seems hesitant to grant such access easily, in view of the French position on Turkey's accession to the EU. Gas de France, in response, started talks with Gazprom and MOL over development of the South Stream project, another pipeline connecting Russia underneath the Black Sea to Hungary to supply natural gas to Europe.

It is clear that the pipeline politics involves many layers of interest, acting sometimes controversially and it is very difficult to foresee an outcome. So contrary to what is argued by many, Turkey's transit strategy cannot rely on resources from Russia for re-export to third markets. It is against the very rationale of the whole venture. In fact, the issue of providing the Nabucco pipeline with Russian natural gas was discussed at the early phases of project development. Gazprom was willing to fill the Nabucco pipeline with Russian natural gas but did not want to allow other shippers to use the pipeline. This meant a greater share for the Russian gas in European markets. The Turkish government, keen to use Nabucco in supporting its EU bid, refused the deal. ${ }^{69}$

Moreover, Russia, possessing 30 per cent of the globe's natural gas reserves, has the capability as well as the will to preserve and preferably increase its already substantial share (30-35 per cent) in the European natural gas markets. There is no commercial interest for Russia to see Turkey promoting competition in association with regional countries. As explained before, Gazprom needs the very same resources in Kazakhstan, Uzbekistan, Turkmenistan and Iran for its own supply strategies for the next decade. ${ }^{70}$

In the meantime, Turkey's only commercial chance for becoming a transit country in natural gas relies on its ability to reach the politically and/or geographically locked countries like Iran, Iraq, Kazakhstan and Turkmenistan. In August 2007, Turkey, despite US protests, signed a memorandum of

\footnotetext{
${ }^{67}$ Yet, Turkmenistan appears to be satisfied with the recent gas sales agreement with Gazprom, offering Turkmenistan $\$ 100$ at the well head (see A. Malashenko, 'Where will Turkmen gas flow?', WPS: Central Asia News, 6 April 2007).

${ }^{68}$ One of the proposals includes providing the existing space in Turkish pipeline infrastructure for the use of Nabucco shippers and starting the construction of Nabucco pipeline in Western Turkey.

${ }^{69}$ 'EU energy coordinator to press Turkey on Nabucco', Turkish Daily Newws, 12 February 2008.

${ }^{70} \mathrm{G}$. Winrow, 'Geopolitics and energy security in the wider Black Sea region', Southeast European and Black Sea Studies, 7(2), June 2007, p. 223.
} 
understanding to develop the two gas pipelines from the South Pars fields (one of the world's greatest untapped gas reserves in the Persian Gulf), to transport Iranian gas for re-sale to Europe. Iran also dropped its objection to transport of Turkmen gas via the new pipeline. ${ }^{71}$ Still, the question remains as to how Turkey will overcome the extremely difficult technical field conditions and raise the required $\$ 8-10$ billion financing for the project under stiff US diplomatic blockage. ${ }^{72}$

In view of all these alternative projects competing for the same resources for throughput it is difficult to foresee how Turco-Russian cooperation will flourish in the energy field. The cooperation in natural gas can hardly go one step further if Turkey is to promote energy security as one of its foreign-policy priorities. The crude oil transit projects bypassing the Turkish straits are not independent of each other: one's success marks another's failure. It can even be expected that the next decade will be marked by competition though restrained by the current political and economic framework.

\section{The future of Turco-Russian partnership}

The oil and gas sector has been the power base of Putin's domestic and international strength. ${ }^{73}$ We could safely assume that any development which could preclude Russian resource development and exports is a policy priority. Hence, Russia has been cautious and coercive, to maintain the stability and control of its transit export routes as well as to keep the emerging competing markets from the Caspian region under control. ${ }^{74}$

In this respect, Turkey's aspiration to emerge as an energy hub and transit country does not serve the Russian interests. This fact already is evident in Russia's recent push towards some deals to counter Turkish transit plans. So, the future energy policies do not seem to be an area where the two states will increase their cooperation and come forward with a breakthrough. The trade in energy will not grow and the overall trade figures may stabilize at around \$25-30 billion.

However, competition in the energy field does not necessarily mean that political relations will worsen. One obvious factor in the Russo-Turkish cooperation in recent times has been a weakening in the US-Turkish relationship. The discontent with US policies in the Black Sea and the Middle East region has provided sufficient stimulus for the growing regional cooperation. Evidently, the US recently decided to give priority to her old ally's needs, or at least to take them seriously. Would Turkey in that event return to the older pattern of 'the great game'?

In a sense Turkey's dependence on the West has increased-roughly a quarter of the Turkish economy is now tied up with international trade, and the value of the currency still depends on IMF support. This of course in the longer term means America and Europe, not Russia. Yet, the opening Russian relationship has shown at least the glimpse of an alternative, if not the happy Eurasian

\footnotetext{
71‘'̇ran'la tarihi gaz anlaşması', News article on NTV MSNBC, 14 July 2007.

${ }^{72}$ Interview with Ali Yasar Hafiz, Director General of NUROL Energy, former Coordinator at the State Pipeline Corporation.

${ }^{73}$ L. Shevtsova, Putin's Russia, The Brookings Institution Press, Washington, DC, 2005, pp. 328-335.

${ }^{74}$ A. C. Lynch, How Russia is Not Ruled: Reflections on Russian Political Development, Cambridge University Press, New York, 2005, pp. 245-246.
} 
togetherness. The pragmatic approach and growth-oriented economic policies of both leaders combined with the already substantial volume of trade indicate that the Turkish-Russian relationship has reached a level that cannot be reversed. Any political matter between the two nations cannot ignore these powerful interests.

Göktuğ Kara holds a PhD in International Relations from Bilkent University, Ankara. He also worked for BOTAS, the State Pipeline Corporation of Turkey, coordinating the international agreements related to the execution of the Baku-Tbilisi-Ceyhan Crude Oil Pipeline Project in Turkey. Currently he is working at the Delegation of the European Commission to Ankara, responsible for the transport sector. The views reflected in this paper are strictly those of the author and do not reflect the views of any institution that the author is associated with.

Address for correspondence: 10. Cadde 51. Sokak 8/17 Umitkoy, Ankara, Turkey. E-mail: karagoktu@hotmail.com 